Erratum

\title{
Erratum: Worqlul, A.W.; et al. Impact of Climate Change on Streamflow Hydrology in Headwater Catchments of the Upper Blue Nile Basin, Ethiopia. Water 2018, 10, 120
}

\author{
Abeyou Wale Worqlul 1,*(D), Yihun Taddele Dile ${ }^{2}$, Essayas Kaba Ayana ${ }^{2}$, Jaehak Jeong ${ }^{1}$, \\ Anwar Assefa Adem ${ }^{3}$ (D) and Thomas Gerik ${ }^{1}$ \\ 1 Blackland Research Center, Texas A\&M AgriLife Research, Temple, TX 76502, USA; \\ jjeong@brc.tamus.edu (J.J.); t-gerik@tamu.edu (T.G.) \\ 2 Spatial Sciences Laboratory, Texas A\&M University, College Station, TX 77843, USA; \\ yihundile@tamu.edu (Y.T.D.); essayaskaba@gmail.com (E.K.A.) \\ 3 Faculty of Civil and Water Resource Engineering, Bahir Dar University, P.O. Box 26, Bahir Dar, Ethiopia; \\ unnxuss@gmail.com \\ * Correspondence: aworqlul@brc.tamus.edu; Tel.: +1-254-774-6020
}

Received: 5 October 2017; Accepted: 24 January 2018; Published: 11 June 2018

The authors wish to make the following correction to their paper [1]: The second author's name should be changed from "Yihun Dile Taddele" to "Yihun Taddele Dile".

The authors would like to apologize for any inconvenience caused to the readers by this change. The change does not affect the scientific results. The manuscript will be updated and the original will remain online on the article webpage.

\section{Reference}

1. Worqlul, A.W.; Dile, Y.T.; Ayana, E.K.; Jeong, J.; Adem, A.A.; Gerik, T. Impact of climate change on streamflow hydrology in headwater catchments of the upper Blue Nile basin, Ethiopia. Water 2018, 10, 120. [CrossRef]

(C) 2018 by the authors. Licensee MDPI, Basel, Switzerland. This article is an open access article distributed under the terms and conditions of the Creative Commons Attribution (CC BY) license (http:/ / creativecommons.org/licenses/by/4.0/). 